\title{
STRATEGI PETANI DALAM PEMASARAN SALAK DENGAN E-COMMERCE (PERDAGANGAN BERBASIS ELEKTRONIK)
}

\author{
Yosua Kon Putra, Siti Astuti dan Totok Sevenek Munanto. \\ Politeknik Pembangunan Pertanian Yogyakarta \\ J1. Kusumanegara No.2, Yogyakarta, 55167 \\ Email: konyosua27@gmail.com
}

\begin{abstract}
SrumdudeSubdistrict is a sub-district with the flagship of Salak commodity with a production of 554,310 KW and continues to increase annually, but there is a problem related to the marketing of the agricultural products, Salak price is not optimal and tends to The harvest. The purpose of this research is to know the strategy of farmers in marketing through e-commerce by specifying segmentation (geographic and demographic) targeting (value, volume, product, price, promotion and distribution) and posisitioning (STP) as well as for Know Salak business strategy using SWOT analysis. The implementation of this study was held in the month of Febuari until July 2019 in Srumdude village, Srumdude District, Magelang Regency, Central Java. Research is done with a descriptive analysis method. The sampling location is purposive and samples were taken using the Harry King Nomogram. Based on the results of the study shows the implementation of marketing strategy only reaches $36.48 \%$ and SWOT analysis shows the strategy that can be applied, namely marketing development through e-commerce and exhibitions, product development into partnerships and Pressing the input cost.
\end{abstract}

Keywords : STP Marketing Strategic, E-commerce, SWOT

\section{LATAR BELAKANG}

Kabupaten Magelang adalah sebuah kabupaten di Provinsi Jawa Tengah. Ibu kota kabupaten ini adalah Kota Mungkid. Salak merupakan salah satu komoditas buah yang menjadi unggulandi Kabupaten Magelang. Produksi salak di Kabupaten Magelang mengalami peningkatan dari tahun ke tahun hingga pada tahun 2017 produksinya mencapai 730.579 kwintal (Statistik Hortikultura Provinsi Jawa Tengah, 2017).

Kecamatan Srumbung adalah sebuah kecamatan di Kabupaten Magelang, Jawa Tengah, Indonesia. Kecamatan Srumbung menjadi daerah penghasil Salak dengan produksi terbesar dibandingkan dengan kecamatan lainnya pada tahun 2017 sebesar 554.310kwintal (Dinas Pertanian, Perkebunan dan Kehutanan, 2017).

Desa Srumbung adalah salah satu desa yang terletak di kecamatan Srumbung kabupaten Magelang Jawa Tengah yang mana desa ini sangat berpotensi di bidang pertanian, komoditas yang menjadi unggulan di desa ini ialah tanaman salak dengan jumlah produksi rata - rata $7.980 \mathrm{kwintal}$ pertahun, namun di balik itu terdapat masalah yang berhubungan dengan pemasaran hasil pertanianberdasarkan data monografi desa yaitu harga salak belum optimal dan cenderung turun pada saat panen raya khususnya pada laporan harga jual di tingkat petani triwulan 4 (Oktober, November Desember Dan Jauari) dengan harga jual berkisar Rp. 3.000,- / kg sedangkan penjualan pada tingkat konsumen akhir berkisar $\mathrm{Rp}$. 6.920,- / kg pada bulan yang sama tahun 2017 di tingkat provinsi dan pada tingkat kabupaten dengan harga 9.000,-/kg sehingga besarnya perbedaan harga atau margin pemasaran yang relatif besar pada tingkat 
konsumen akhir berkisar 43,35\% pada tingkat provinsi dan $300 \%$ pada tingkat kabupaten sehingga hal tersebut mengakibatkan hasil panen yang di jual dengan harga yang mahal dan lebih menguntungkan dipihak konsumen akhir (Statistik Harga Konsumen Pertanian Subsektor Tanaman Pangan, Hortikultura dan Tanaman Perkebunan Rakyat 2017).Penyebab lain yang didapat dari data programa yaitu bahwa pemasaran hasil pertanian salak di desa srumbung masih konvensial dimana petani menjual hasil panen ke pengepul, lalu kepihak produsen dan terakhir konsumen yang membutuhkan salak (Programa Kecamatan Srumbung, 2017).

Dari permasalahan diatas menyebabkan tingginya akumulasi keuntungan yang diambil dari setiap pelaku dalam rantai pemasaran. Sehingga petani harus bisa memilih rantai terpendek dalam memasarkan produknya. Untuk memaksimalkan potensi agribisnis tersebut, dibutuhkan strategi yang efektif dalam pemasarannya. Salah satu usahanya adalah dengan membangun sistem peniagaan berbasis elektronik dengan menggunakanecommercedi bidang pertanian sebagai strategi petani dalam pemasaran salak. Perniagaan berbasis e-commerce dapat dijadikan alternatif bagi petani, kemudian dapat juga dijadikan sebagai media dalam menentukan segmentasi, berbagai target pemasaran seperti promosi, komunikasi dan informasi serta posisi usaha saat ini (STP).

Sehingga dalam kondisi tersebut ilmu pengetahuan dan teknologi perlu di tanamkan kepada para petani agar mereka dapat mengetahui informasi pasar yang sedang berkembang pada saat ini kemudian dalam usaha salak perlu untuk mengidentifikasi kekuatan atau potensi, kelemahan, peluang dan ancaman usaha.

\section{Rumusan Masalah}

Berdasarkan latar belakang permasalahan maka dapat dirumuskan rumusan masalah sebagai berikut :

1. Bagaimana strategi petani dalam pemasaran melalui e-commerce dengan menentukan segmentasi geografis, segmentasi demografis, target value, target volume, target produk, target harga, target promosi, target distribusidan posisitioning (STP) ?

2. Bagaimana perencanaan strategi usaha salak dengan menggunakan analisis SWOT?

\section{Batasan Masalah}

Batasan masalah dalam kajian ini adalah,

1. Penelitian ini terbatas pada kajian mengenai strategi petani dalam pemasaran melalui $e$ - commerce (perdagangan berbasis elektronik) dengan menentukan segmentasi geografis, segmentasi demografis, target value, target volume, target produk, target harga, target promosi, target distribusidan posisitioning (STP) serta strategi usaha salak di Desa Srumbung dengan menggunakan analisis SWOT.

2. Petani yang menjadi responden dalam kajian ini adalah petani salak dan petani pemilik lahan.

\section{Tujuan}

Berdasarkan latar belakang dan rumusan masalah di atas, maka penelitian strategi pemasaran hasil pertanian ini bertujuan untuk : 
1. Untuk mengetahui strategi petani dalam pemasaran melalui e-commerce dengan menentukan segmentasi geografis, segmentasi demografis, target value, target volume, target produk, target harga, target promosi, target distribusidan posisitioning (STP).

2. Untuk mengetahui strategi usaha salak di Desa Srumbung dengan menggunakan analisis SWOT.

\section{Manfaat}

1. Bagi mahasiswa, merupakan proses belajar dalam mengembangkan pola pikir agar dapat mengidentifikasi dan menganalisa masalah serta menyusun strategi penyelesaian masalah dengan tepat dan dilandasi dengan kaidah ilmiah, sebagai bahan penyusun penulisan kajian proyek akhir pada program pendidikan reguler diploma IV di Politeknik Pembangunan Pertanian Yogyakarta Magelang (POLBANGTAN YOMA).

2. Bagi pemerintah dan instasi terkait, diharapkan dapat menjadi bahan informasi dan landasan dalam mengambil kebijakan selanjutnya.

3. Bagi petani, kajian ini memberikan gambaran tentang strategi petani dalam pemasaran salak dengan $e$-commerce (Perdagangan Berbasis Elektronik) sehingga petani dapat memperluas pangsa pasar atau jejaring pemasaran.

\section{TINJAUAN PUSTAKA}

\section{Dasar Teori}

Strategi pemasaran merupakan bagian penting dari sistem pemasaran secara keseluruhan dan merupakan langkah awal untuk membuat rencana pemasaran. Strategi pemasaran terdiri atas 3 komponen utama meliputisegmentasi,targetingdanpositioning. Strategi pemasaran sering disingkat menjadi simbol STP. Setelah melakukan tahapan pembuatan strategi pemasaran maka langkah berikutnya adalah pembuatan taktik pemasaran yang meliputi diferensiasi, bauran pemasaran dan penjualan. Adapun tujuan dari diferensiasi adalah pembedaan produk atau bisnis kita dengan kompetitor atau orang lain. Pembedaan ini diperlukan utuk memberikan nilai lebih dibandingkan dengan kompetitor yang ada. Bauran marketing mutlak dilakukan untuk pembuatan bisnis atau produk yang terdiri atas $4 \mathrm{P}$ yaitu producti (produk), price (harga), promotion (promosi) dan placement (distribusi) dalam pembuatan strategi pemasaran (Wijayanti, 2012).

Menurut Gitosudarmo (2000) dalam Rahmat (2012) Untuk membuat suatu rencana kita harus mengevaluasi faktor ekstern maupun faktor internal. Analisis faktor-faktor haruslah menghasilkan adanya kekuatan (strength), mengetahui kelemahan (weakness). Sedangkan analisis terhadap faktor eksternal harus dapat mengetahui kesempatan (opportunity) serta dapat mengetahui pula ancaman (treath) yang dialami oleh organisasi yang bersangkutan. Analisis tersebut disebut analisis SWOT yang merupakan singkatan dari keempathal tersebut (Gitosudarmo, 2000).

Menurut Laudon (2010) dalam Sulthoni (2015), e-commerceadalah penggunaan internet dan Bloguntuk transaksi atau lebih formal e-commerce didefinisikan sebagai transaksi perdagangan yang di mungkinkan secara digital antar organisasi 
dengan organisasi atau dengan individual serta antar individual dengan individual. Menurut Baum, e-commerceadalah satu setdinamis teknologi, aplikasi, dan proses bisnis yang menghubungkan perusahaan, konsumen, dan komunitas tertentu melalui transaksi elektronik dan perdagangan barang pelayanan, dan informasi yang dilakukan secara elektronik.Fuady (2005) dalam Nugrahani (2011)e-commerce diartikan sebagai suatu proses bisnis dengan memakai teknologi elektronik yang menghubungkan antara perusahaan, konsumen dan masyarakat dalam bentuk transaksi elektronik dan pertukaran atau penjualan barang service dan informasi secara elektronik.

\section{METODE PELAKSANAAN}

\section{Waktu dan Tempat}

Waktu pelaksanaan kajian ini dilaksanakan pada bulan Febuari sampai dengan Juli 2019 di Desa Srumbung Kecamatan Srumbung, Kabupaten Magelang, Jawa Tengah.

\section{Metode Penelitian}

Berdasarkan tujuannya kajian ini termasuk dalam tipe penelitian deskriptif. Penelitian ini bertujuan menggambarkan secara cermat karakteristik dari suatu gejala atau masalah yang diteliti. Penelitian deskriptif juga fokus pada pertanyaan dasar "bagaimana" dengan berusaha mendapatkan dan menyampaikan fakta - fakta dengan jelas, teliti dan lengkap tanpa banyak detail yang tidak penting (Silalahi, 2012).

\section{Analisis Data}

Analisis data yang digunakan dalam kajian ini dengan cara mendeskripsikan.
Statistik deskriptif antara lain adalah penyajian data melalui tabel, grafik, diagram lingkaran, pictogram, perhitungan modus, median, mean, (pengukuran tendensi sentral), perhitungan desil, presentil, perhitungan penyebaran data melalui perhitungan rata - rata dan standar deviasi, perhitungan persentase (Sugiyono, 2018).

Sedangkan skala pengukuran yang digunakan ialah dengan menggunakan skala guttman. Menurut Sugiyono (2018), menyatakan bahwa skala pengukuran dengan tipe ini akan didapat jawaban tegas yaitu "yatidak"; "benar-salah"; "pernah-tidak pernah"; "positif-negatif"; dan lain - lain. (Sugiyono, 2018).

Data - data yang ditemukan kemudian disusun dan dianalisis dengan analisa SWOT, dilakukan melalui tiga tahap analisis yaitu pertama tahap pengumpulan data yang berisikan evaluasi faktor eksternal, evaluasi faktor internal dan pembuatajn mantrik profil kompetitif, tahap kedua yaitu tahap analisis atau Tahap Pencocokan (Matching Strage) yang berisikan pembuatan matrik SWOT, pembuatan matrik Internal - Eksternal (IE) dan pembuatan matrik grand strategy dan tahap ketiga yaitu tahap pengambilan keputusan dengan pembuatan matrik QSPM (Rangkuti, 2018).

\section{HASIL DAN PEMBAHASAN}

Hasil dan Pembahasan Strategi Pemasaran Segmentasi, Targeting dan Posisitioning (STP)

Rata - rata pengisian kuisioner oleh responden sebanyak 32 petani dapat dilihat pada Tabel 1. 
Tabel 1. Strategi Segmentasi, Targeting dan Posisitioning Di Desa Srumbung

\begin{tabular}{rlrrrr}
\hline \multirow{2}{*}{ No } & \multirow{2}{*}{ Komponen Strategi Pemasaran STP } & \multicolumn{2}{c}{ Jawaban Petani } & \multicolumn{2}{c}{ Persentase (\%) } \\
\cline { 3 - 6 } & & \multicolumn{1}{c}{ Ya } & Tidak & \multicolumn{1}{c}{ Ya } & Tidak \\
\hline 1 & Segmentasi geografis & 1 & 31 & 3,23 & 96,77 \\
2 & Segmentasi demografis & 2 & 30 & 6,25 & 93,75 \\
3 & Target value & 23 & 9 & 71,87 & 28,12 \\
4 & Target volume & 18 & 14 & 56,25 & 43,75 \\
5 & Target produk & 26 & 6 & 81,25 & 18,75 \\
6 & Target harga & 2 & 30 & 6,25 & 93,75 \\
7 & Target promosi & 0 & 32 & 0 & 100 \\
8 & Target distribusi & 1 & 31 & 3,23 & 96,77 \\
9 & Positioning & 32 & 0 & 100 & 0 \\
\hline \multicolumn{2}{c}{ Total } & & & 328,33 & 571,66 \\
\hline \multicolumn{2}{c}{ Rata - Rata }
\end{tabular}

Dari Tabel 1 segmentasi, targeting dan posisitioningmenunjukkanbahwa,segmentasi geografis bertujuan untuk mengukur petani dalam menentukan target pasar berdasarkan desa - kota, pulau, negara.Strategi pemasaran dengan segmentasi geografis petani yang menentukan target pemasaran berdasarkan lingkup desa, perkotaan, pulau dan luar negeri sebesar 3,23\% petani masuk dalam kegori sesuai dengan indikator sedangkan 96,77 $\%$ petani belum menentukan segmentasi geografis secara menyeluruh masuk dalam kategori belum sesuai indikator. Strategi pemasaran dengan menentukan segmentasi geografis dalam pemasaran salak segar di Desa Srumbung berdasarkan hasil kajian pada lingkup desa menargetkan pemasaran desa Turi, Ngablak, Srumbung, Ngargosoko, Ngablak, Tegalrandu, Mranggen, Banyuadem, Bedaung, Babajan, Cilehan, pada lingkupkota menargetkan kota Sleman, Yogyakarta, Magelang, Jakarta, Semarang, Solo, Tempel, Mojokerto, Secang, Cilacap, Temanggung, Surabaya, pada lingkup pulau menargetkan pulau Sumatra \& Kalimantan dan pada lingkup negara menargetkan negara ASEAN.Berdasarkan hasil analisis karakteristik petani, responden dalam menentukan segmentasi geografis secara menyeluruh belum sesuai indikator dapat disebabkan mayoritas petanibelum pernah mengikuti pelatihan pemasaran produk hasil pertanian.

Segmentasi demografis bertujuan untuk mengukur petani dalam pengelompokan sasaran konsumen berdasarkan keseragaman pendudukan di lihat dari kelompok umur, jenis kelamin dan tingkat ekonomi namun dalam pelaksanaanya yang diukur hanya berdasarkan tingkat ekonomi. Strategi pemasaran dengan segmentasi demografis petani yang menentukan target konsumen berdasarkan kelas ekonomi sebesar 6,25\% petani masuk dalam ketegori sesuai dengan indikator sedangkan $93,75 \%$ petani belum menentukan segmentasi demografis secara menyeluruh masuk dalam kategori belum sesuai indikator.Strategi pemasaran dengan menentukan segmentasi demografis dalam pemasaran salak segar di Desa Srumbung berdasarkan hasil kajian menargetkan sasaran konsumen kelas menegah dan menegah keatas. 
Berdasarkan hasil analisis karakteristik petani, responden dalam menentukan segmentasi demografis secara menyeluruh belum sesuai indikator dapat disebabkan mayoritas petanibelum pernah mengikuti pelatihan pemasaran produk hasil pertanian. Menurut Saputra (2012), segmentasi demografis adalah adalah dasar paling umum yang digunakan untuk menetapkan segmentasi kelompok pelanggan. Alasannya adalah tingkat variasi kebutuhan, keinginan dan penggunaan konsumen sering berhubungan erat dengan variabel demografis.

Target value bertujuan untuk mengukur petani dalam menentukan jumlah keuntungan dalam \% atau rupiah yang diinginkan petani. Strategi pemasaran dengan target value petani yang menentukan target jumlahkeuntungan dalam $\%$ atau rupiah sebesar $71,87 \%$ petani masuk dalam kategori sesuai indikator sedangkan $28,12 \%$ petani belum menentukan target value masuk dalam kategori belum sesuai indikator. Strategi pemasaran dengan menentukan target value dalam pemasaran salak segar di Desa Srumbung berdasarkan hasil kajian menargetkan keuntungan 2.000 - 5.000,-.Berdasarkan hasil analisis karakteristik petani, responden dalam menentukan target value secara menyeluruh sesuai indikator dapat disebabkan rata rata tingkat pendidikan petani tinggi. Target volume bertujuan untuk mengukur petani dalam menentukan target volume salak yang dijual. Strategi pemasaran dengan target volume petani yang menentukan target jumlah produk yang akan dijual sebesar 56,25\% petani masuk dalam kategori sesuai indikator sednagkan $43,75 \%$ petani belum menentukan target volume masuk dalam kategori belum sesuai indikator.Strategi pemasaran dengan menentukan target volume dalam pemasaran salak segar di Desa Srumbung berdasarkan hasil kajian menunjukkan kemampuan dalam produksi dan permintaan salak segar menargetkan produksi 2,5 ton/minggu. Berdasarkan hasil analisis karakteristik petani, responden dalam menentukan target volume secara menyeluruh belum sesuai indikator dapat disebabkan luas kepemilikan lahan petani termasuk dalam kategori sempit kurang dari 0,5 Ha.

Target produk bertujuan untuk mengukur petani dalam mengidentifikasi produk keunggulan daerah yang mempunyai nilai ekonomis dan berdaya saing tinggi serta menyerap tenaga kerja dalam jumlah besar. Strategi pemasaran dengan target produk petani yang dapat mengidentifikasi produk keunggulan daerah yang mempunyai nilai ekonomis dan berdaya saing tinggi serta menyerap tenaga kerja dalam jumlah besar sebesar 81,25\% petani masuk dalam kategori sesuai indikator sedangkan $18,75 \%$ petani belum menentukan target produk masuk dalam kategori belum sesuai indikator. Strategi pemasaran dengan menentukan taget produk berdasarkan hasil kajian menargetkan komoditas salak segar sebagai komoditas unggulan di Desa Srumbung. Berdasarkan hasil analisis karakteristik petani, responden dalam menentukan target produk secara menyeluruh sesuai indikator dapat disebabkan mayoritas petani banyak yang berbudidaya salak sehingga petani dapat mengidentifikasi produk keunggulan daerah yang mempunyai nilai ekonomis dan berdaya saing tinggi serta menyerap tenaga kerja dalam jumlah besar dan hal tersebut menunjukkan minat petani 
dalam mengembangkan produk unggulan daerah berpeluang sangat besar.

Target harga bertujuan untuk mengukur petani dalam menentukan target harga. Strategi pemasaran dengan target harga petani yang dapat menentukan harga dengan tahapan melakukan survey pasar untuk melihat harga produk kompetitor, memperkirakan permintaan pasar terhadap produk, memperkirakan biaya produksi (COGS : cost of good sales) dan tahap menetapkan harga akhir sebesar 6,25\% petani masuk dalam kategori sesuai indikator sedangkan 93,75\% petani belum menentukan target harga secara menyeluruh masuk dalam kategori belum sesuai indikator. Strategi pemasaran dengan menentukan target harga dalam pemasaran salak segar di Desa Srumbung berdasarkan hasil kajian menargetkan harga jual berkitar 3.000 - 8.000,-/kg pada tingkat petani. Berdasarkan hasil analisis karakteristik petani, responden dalam menentukan target harga secara menyeluruh belum sesuai indikator dapat disebabkan mayoritas petanibelum pernah mengikuti pelatihan pemasaran produk hasil pertanian.

Target promosi bertujuan untuk mengukur petani dalam menentukan target promosi dengan metode promosi seperti above the line (ATL), below the line (BTL) dan e-commerce. Berdasarkan hasil kajian target promosi menunjukkan seluruh petani belum menentukan target promosi secara menyeluruh sesuai dengan indikator sehingga kegiatan promosi yang dilakukan saat ini masih secara sederhana dengan cara penjualan langsung.Strategi pemasaran dengan menentukantarget promosi dalam pemasaran salak segar di Desa Srumbung berdasarkan hasil kajian menargetkan kegiatan promosi pada penjualan langsung dengan kemitraan dan penjualan secara tidak langsung dengan pembuatan poster, pemanfaatan media e-commerce (Facebook, Whats'app, Agromaret, Petani, Google Maps, Blog).Berdasarkan hasil analisis karakteristik petani, responden dalam menentukan target promosi secara menyeluruh belum sesuai indikator dapat disebabkan mayoritas petanibelum pernah mengikuti pelatihan pemasaran produk hasil.

Target distribusi bertujuan untuk mengukur petani dalam menentukan target distribusi dalam memasarkan produk melalui modern market, tradisional market dan whole seller. Strategi pemasaran dengan target distribusi petani yang dapat menentukan target distribusi dalam memasarkan produk melalui modern market, tradisional market dan whole seller sebesar 3,23\% petani masuk dalam kategori sesuai indikator sedangkan 96,77 $\%$ petani belum menentukan target distribusi secara menyeluruh masuk dalam kategori belum sesuai indikator.Strategi pemasaran dengan menentukantarget distribusi dalam pemasaran salak segar di Desa Srumbung berdasarkan hasil kajian menargetkan modern market ialah wisata religi, pameran seropadan, carrefour, tradisional market ialah pasar sayur srumbung danwhole seller ialahexport ASEAN melalui CV. Buah Angkasa dan PT. AMS Jakarta.Berdasarkan hasil analisis karakteristik petani, responden dalam menentukan target distribusi secara menyeluruh belum sesuai indikator dapat disebabkan mayoritas petanibelum pernah mengikuti pelatihan pemasaran produk hasil pertanian. 
Positioning bertujuan untuk mengukur petani dalam identifikasi dan analisis posisi produk saat ini dibandingkan dengan pesaing. Strategi pemasaran dengan positioning petani yangdapat mengidentifikasi nilai tambah produk dibandingkan dengan pesaing sebesar $100 \%$ dapat mengidentifikasi nilai tambah produk dibandingkan dengan pesaing sesuai indikator.Strategi pemasaran dengan menentukan positioning dalam pemasaran salak di Desa Srumbung berdasarkan hasil kajian menunjukkan unggulan salak Srumbung dibandingkan dengan daerah lain ialah lebih besar, lebih manis, lebih tahan lama (10 hari), organik, warna kulit cerah dan isi buah tebal.Berdasarkan hasil analisis karakteristik petani, responden dalam menentukan nilai tambah produk secara menyeluruh dibandingkan daerah lainsesuai indikator dapat disebabkan mayoritas petani bermata pencaharian petani/wirauaha sehingga dapat mengidentifikasi kunggulan salak di Desa Srumbung dibandingkan dengan desa lain.

Dari Tabel 21 analisis strategi segmentasi, targeting dan positioning (STP) dapat diketahui target promosi menunjukkan presentase terendah dalam penerapan sebesar $100 \%$ dan penerapan strategi Segmentasi, Targeting dan Posisitioning (STP) secara menyeluruh sebesar 36,48 \%.

\section{Hasil dan Pembahasan Analisis SWOT} Evaluasi Faktor Eksternal (Faktor Luar)

Berdasarkan hasil kajian evaluasi faktor eksternal usaha budidaya salak Desa Srumbung menunjukkan struktur pasar dari sisi pembeli, masuk dalam kategori pasar persaingan sempurna, adanya fasilitasi kegiatan promosi salak dari dinas pertanian melalui pameran Jateg Fair dan Seropadan Agro Expo, terdapat lembaga exportir memberi pengaruh peluang yang sangat berpengaruh atau sangat besar daripada peluang lainnya dengan skor 4 . Hal tersebut dapat disebabkan banyaknya permintaan dari sisi pembeli sehingga usaha salak sangat berpeluang untuk dikembangkan selain itu terdapat lembaga exportir salak di Desa Srumbung sehingga salak berpeluang export dan bantuan dari dinas pertanian Magelang dalam menfasilitasi kegiatan promosi salak ditingkat petani ke konsumen akhir melalui kegiatan pameran.

Sedangkan dari sisi ancaman menunjukkan struktur pasar dari sisi penjualan salak masuk dalam kategori persaingan sempurna, terjadinya persaingan dengan hasil panen buah lainnya dan harga salak tidak selalu stabil memberi pengaruh ancaman yang sangat berpengaruh atau sangat besar daripada ancaman lainnya dengan skor 1 . Hal tersebut dapat disebabkan banyak petani yang berbudidaya salak sehingga terjadinya persaingan terutama pada saat panen raya menyebabkan harga cenderung turun dan tidak selalu stabil.

\section{Evaluasi Faktor Internal(Faktor Dalam)}

Berdasarkan hasil kajian evaluasi faktor internal usaha budidaya salak Desa Srumbung menunjukkan kualitas salak lebih besar, lebih manis dan tahan lama,salak sudah organik, pengurus gapoktan sudah melek teknologi melalui internet facebook dan whats'app memberi pengaruh kekuatan yang sangat berpengaruh atau sangat besar daripada kekuatan lainnya dengan skor 4 
dalam usaha berbudaya salak. Hal tersebut dapat disebabkan kualitas salak Desa Srumbung dapat bersaing dengan desa lainnya serta didukung dengan kualitas yang sudah organik, lebih besar, manis dan tahan lama sehingga akan lebih mudah dipasarkan melalui pengurus gapoktan yang sudah melek teknologi melalui pemasaran internet.

Sedangkan dari sisi kelemahan menunjukkan mayoritas petani belum membuat analisa usaha, mayoritas petani belum menjual salak pada konsumen akhir dan mayoritas petani belum mengetahui teknologi pemasaran melalui internet dengan media e-commerce memberi pengaruh kelemahan yang sangat berpengaruh atau sangat besar daripada kelemahan lainnya dengan skor 4.

\section{Pembuatan Matrik Kompetitif}

Analisis matrik kompetitif dapat diketahui kualitas salak di Desa Nglumut dan Kaliurang lebih baik dari pada Desa Srumbung sehingga strategi yang dapat di gunakan ialah menentukan target segmentasi.

\section{Pembuatan Matrik SWOT}

Analisis SWOT dapat diketahui bahwa pemurusan strategi pemasaran salak di Desa Srumbung terbagi menjadi 4 bagian komponen yaitu SO, WO, ST dan WT sebagai berikut,

strategi yang menggunakan kekuatan untuk memanfaatkan peluang (SO) yaitu memaksimalkan nilai tambah kualitas salak lebih besar, manis, tahan lama dan organik sebagai upaya memenuhi permintaan pasar buah segar persaingan sempurna dan pasar salak olahan, pengembangan pasar melalui gapoktan dengan memanfaatkan fasilitasi kegiatan promosi salak dari dinas pertanian melalui pameran Jateg Fair dan Seropadan Agro Expo, lembaga exportir dan teknologi pemasaran e-commerce dan strategi penghematan biaya input dengan kemitraan seluruh petani salak Desa Srumbung dengan pengembangan usaha penangkaran benih dan pupuk organik dengan memanfaatkan bantuan dari Dinas pertanian dan pemda daerah untuk memfasilitasi usaha budidaya pertanian salak.

Selanjutnya ialalah strategi yang Meminimalkan kelemahan untuk memanfaatkan peluang (WO) yaitu kemitraan dengan lembaga pertanian terkait dalam pengembangan pemasaran melalui pameran Jateg Fair,Seropadan Agro Expo dan eksportir, meningkatkan kualitas SDM dengan pelatihan pemasaran dan usaha budidaya slaak dari dinas pertanian dan mensertifikasi lahan pertanian salak organik dan memaksimalkan sumber mata air untuk kegiatan irigasi dengan fasilitasi dinas pertanian dan pemda. Sehingga dari strategi tersebut diharapkan petani lebih termotivasi dalam menjual salak secara bersama - sama.

Selajutnya ialah strategi yang menggunakan kekuatan untuk mengatasi ancaman (ST) yaitu strategi meminimalisir ancaman perubahan iklim dan gejala alam dengan cara memanfaatkan sumber informasi melalui IT melalui pengurus gapoktan yang sudah melek teknologi untuk mencari solusi dalam pemecahan masalah hama penyakit dan upaya mengelabui spesifik lokasi budidaya salak dan strategi meminimalisir ancaman dalam pemasaran yaitu dengan diversifikasi penjualan dengan mengembangkan jejaring dengan memanfaatkan teknologi pemasaran 
melalui internet (E-commerce).

Terakhir strategi yang meminimalkan kelemahan dan menghindari ancaman (WT) yaitu meningkatkan kualitas SDM petani dalam kegiatan pemasaran, pembuatan strategi pemasaran dan analisa usaha budidaya salak, strategi yang dapat digunakan untuk menghindari ancaman yaitu memanfaatkan sumber informasi melalui IT melalui pengurus gapoktan yang sudah melek teknologi untuk mencari solusi dalam pemecahan masalah hama penyakit dan upaya mengelabui spesifik lokasi budidaya salak dan strategi yang dapat digunakan untuk menghindari ancaman dalam pemasaran yaitu petani mengembangkan jejaring pemasaran sendiri dan model produk yang unik sendiri sehingga petani memonopoli produk tersebut, monopoli yaitu satu penjual dengan produk unik atau tidak dapat didistribusikan produk lainnya.

\section{Pembuatan Matrik Internal - Eksternal (IE)}

Analisis internal - eksternal (IE) menunjukkan bahwa posisi usaha pada saat ini terletak di kuadran 1 dan 2 yaitu indikator usaha sedang tumbuh dan berkembang sehingga strategi yang diperlukan selanjutnya ialah strategi konsentrasi melalui integrasi vertikal dan horizontal.

\section{Pembuatan Matrik Grand Strategy}

Analisis matrik grand strategy menunjukkan keadaan usaha agribisnis salak di Desa Srumbung masuk pada kuadran I sehingga strategi yang dibutuhkan ialah interasi vertikal, difersifikasi konglomerat, pengembangan pasar dan produk..

\section{Pembuatan Matrik Quantitative Strategic}

\section{Planning Matrix (QSPM)}

Analisis matrik QSPM menunjukkan pengembangan pemasaran melaui e-commerce dan pameran menjadi prioritas utama dalam strategi pemasaran. Urutan strategi hasil analisis matrik QSPM dalam pengembangan usaha salak di Desa Srumbung Kecamantan Srumbung disajikan pada Tabel 2 berikut,

Tabel2. Quantitative Strategic Planning Matrix (QSPM)

\begin{tabular}{clcc}
\hline Urutan & Alternatif Strategi & $\begin{array}{l}\text { Total } \\
\text { TAS }\end{array}$ & Peringkat \\
\hline 1 & $\begin{array}{l}\text { P e n g e m b a n g a n } \\
\text { pemasaran melaui } \\
\text { e-commerce dan } \\
\text { pameran }\end{array}$ & 5,68 & I \\
& $\begin{array}{l}\text { P e n g e m b a n g a n } \\
\text { produk }\end{array}$ & 5,36 & III \\
3 & $\begin{array}{l}\text { Kemitraan } \\
4\end{array}$ & 5,59 & II \\
& Menekan Biaya Input & 4,01 & IV \\
\hline
\end{tabular}

\section{KESIMPULAN DAN SARAN}

\section{Kesimpulan}

Berdasarkan analisis hasil kajian strategi petani dalam pengembangan pemasaran salak dengan e-commerce (perdagangan berbasis digital) di Desa Srumbung Kecamatan Srumbung Kabupaten Magelang dapat disimpulkan bahwa:

1. Strategi pemasaran melalui e-commerce dengan menentukan segmentasi geografis baru mencapai 3,23\% sesuai indikator, segmentasi demografis baru mencapai 6,25\% sesuai indikator, target value baru mencapai $71,87 \%$ sesuai indikator, target volume baru mencapai $56,25 \%$ sesuai indikator, target produk baru mencapai $81,25 \%$ sesuai indikator, target harga baru mencapai $6,25 \%$ sesuai indikator, target promosi $100 \%$ belum menerapkan sesuai indikator, target distribusi baru mencapai 
$3,12 \%$ sesuai indikatordan posisitioning (STP) mencapai $100 \%$ sesuai indikator.

2. Perencanaan strategi usaha salak di Desa Srumbung dengan menggunakan analisis SWOTdapat diketahui 4 jenis strategi ialah pengembangan pemasaran melaui e-commerce dan pameran, pengembangan produk, kemitraan dan penekanan biaya input.

\section{Saran - Saran}

Berdasarkan hasil analisis pembahasan dan kesimpulan maka saran - saran yang dapat diberikan ialah sebagai berikut,

1. Suksesnya dalam menjalankan strategi diperlukan komitmen yang kuat dan disiplin dalam menjalankan strategi yang telah disusun karena sehebat apapun strategi yang telah di miliki, tanpa kesungguhan niat dan kediplinan dalam menjalankannya. Bisa hampir dipastikan strategi yang dimiliki sangat mungkin tidak terealisasikan sesuai harapan.

2. Strategi yang telah disusun kemungkinan dapat berubah dalam pelaksanaannya bergantung situasi dan kondisi internal dan eksternal pelaku usaha tersebut sehingga di perlukan evaluasi dan pengukuran untuk menilai strategi yang telah di jalankan secara berkala.

\section{DAFTAR PUSTAKA}

Badan Pusat Statistik. 2008 - 2017. Perkembangan Rata-Rata Harga Konsumen Perdesaan. Jawa Tangah.

Badan Pusat Statistik. 2015 - 2017. Statistik
Pertanian Hortikultura. Jawa Tengah.

BPPK. 2017. Programa Penyuluhan Pertanian Perikanan Dan Kehutanan. Kecamatan Srumbung.

Dinas Pertanian, Perkebunan, dan Kehutanan. 2009-2018. Produksi Buah-buahan menurut Triwulanan. Kabupaten Magelang.

Nugrahani, D.S. 2011. E-commerceUntuk Pemasaran Produk Usaha Kecil Dan Menengah. Jurnal Manajemen Dan Bisnis. Januari Vol. 1.

Rangkuti, F. 1997. Teknik Membedah Kasus Bisnis ANALISIS SWOT. Jakarta. 245 hal.

Rahmat, M.R. 2012. Analisis Strategi Pemasaran Pada Pt. Koko Jaya Prima. Skripsi. Program Pascasarjana, Universitas Hasanuddin. Makassar.

Saputra, A.W.A. 2012. Strategi Penerapan Segmentation, Targeting dan Positioning Pada PT.Sekarnusa Kreasi Indonesia. Skripsi. Program Pascasarjana, Universitas Sebelas Maret. Surakarta.

Silalahi, U. 2012.Metode Penelitian Sosial. PT.Refika Aditama, Bandung.

Sugiyono. 2018. Metode Penelitian Kuantitatif, Kualitatif dan Research \& Developmen. Alfabeta. Bandung.

Sulthoni, A dan Achlison, U. 2015. Sistem Informasi E-commerce Pemasaran Hasil Pertanian Desa Kluwan Berbasis Blog. Jurnal E-Bisnis. April Vol 8 (1).

Wijayanti, T. 2012. Marketing Plan Dalam Bisnis. Jakarta. 223 hal. 